\title{
HYPONATREMIA IN VISCERAL LEISHMANIASIS
}

\begin{abstract}
SUMMARY
There are few reports linking hyponatremia and visceral leishmaniasis (kala-azar). This is a study of 55 consecutive kala-azar patients and 20 normal individuals as a control group. Hyponatremia and serum hypo-osmolality were detected in $100 \%$ of kalaazar patients. High first morning urine osmolality ( $750.0 \pm 52.0$ vs. $\left.894.5 \pm 30.0 \mathrm{mOsm} / \mathrm{kg} \mathrm{H}_{2} \mathrm{O}, \mathrm{p}<0.05\right)$, and high 24-hour urine osmolality ( $426.0 \pm 167.0$ vs. $\left.514.6 \pm 132.0 \mathrm{mOsm} / \mathrm{kg} \mathrm{H} \mathrm{O}_{2} \mathrm{p}<0.05\right)$ demonstrated persistent antidiuretic hormone secretion. Urinary sodium was high $(82.3 \pm 44.2$ vs. $110.3 \pm 34.7 \mathrm{mEq} / \mathrm{L}, \mathrm{p}<0.05)$. Low seric uric acid occurred in $61.8 \%$ of patients and increased fractional urinary uric acid excretion was detected in $74.5 \%$ of them. Increased glomerular filtration rate was present in $25.4 \%$ of patients. There was no evidence of extracellular volume depletion. Normal plasma ADH levels were observed in kala-azar patients. No endocrine or renal dysfunction was detected. It is possible that most hyponatremic kala-azar patients present the syndrome of inappropriate antidiuretic hormone secretion.
\end{abstract}

KEYWORDS: Hyponatremia; Hypo-osmolality; Hypouricemia; Syndrome of inappropriate antidiuretic hormone secretion; Visceral leishmaniasis.

\section{INTRODUCTION}

Visceral leishmaniasis (kala-azar) is a zoonosis that affects predominantly young people, and which has extensive public health impact in tropical and subtropical regions of the world. It is estimated, that more than 12 million individuals are infected by various Leishmania species in 88 countries, with an estimated 1.5 to 2 million clinical cases $^{4}$. The visceral form of the disease, fatal if not treated, is caused in Brazil by Leishmania donovani chagasi, species associated with endemic outbreaks. Kala-azar causes an intense immune dysfunction with polyclonal activation of B lymphocytes and depression in cellular and humoral immunities ${ }^{10}$. Visceral leishmaniasis progresses with intense inflammatory alterations in vital organs such as the lungs, liver, spleen, kidneys, digestive tract and bone marrow. Interstitial pneumonitis is common during the active phase of the disease, and necropsy studies have shown the prevalence of interstitial pneumonitis to be around $76.8 \%$ of human cases. A dry cough is a constant symptom of kala-azar, that persists from the onset of the disease throughout its entire clinical course. The parasitary etiology of the pneumonitis can be confirmed by immunohistochemical reaction using anti-leishmania polyclonal specific anticorps ${ }^{12}$. Lobar pneumonia is a frequent complication of more debilitated patients, when secondary pulmonary bacterial infections occur. In a study involving 50 children with kala-azar, the diagnostic of lobar pneumonia occurred in 10\% of cases and Staphylococcus aureus and Streptococcus pneumoniae were the most frequent etiologic agents ${ }^{36}$. Hyponatremia has been decribed in children with visceral leishmaniasis ${ }^{25}$ and prospective studies of patients with chronic forms of kala-azar have shown the presence of hyponatremia and high daily sodium urinary excretion, characteristics that persist during all active phases of the disease $^{20,21}$, returning to normal serum levels after glucantime treatment. Hyponatremia and high sodium urinary excretion are features of the syndrome of innapropriate antidiuretic hormone secretion, of adrenal insufficiency or carriers of renal sodium wasting diseases ${ }^{5,15}$.

The aim of the present study is to describe the characteristics of the hyponatremia observed in chronic forms of kala-azar.

\section{PATIENTS AND METHODS}

This study included 55 patients admitted to Hospital São José de Doenças Infecciosas and to the Hospital Geral de Fortaleza between 2002 and 2008. Diagnosis of kala-azar was confirmed by the finding of L. donovani, subspecie chagasi in bone marrow smears. Patients with arterial hypertension, systemic diseases and history of renal diseases are excluded. HIV positive patients or that having specific pulmonar diseases do not participate from the investigation. Patients with decreased renal function $\left(\mathrm{Ccr}<85 \mathrm{~mL} / \mathrm{min} / 1.73 \mathrm{~m}^{2}\right)$ were rejected because the possibility of alterations of extracellular volume of these patients. Thirteen patients were excluded because they did not satisfy the criteria of the present investigation. All patients received a hospital diet with $2 \mathrm{~g} / \mathrm{kg}$ body weight of animal protein and a daily ingestion of 10 to $12 \mathrm{~g}$ of sodium chloride. No medication was administered during the study period, and

(1) Instituto de Nefrologia do Ceará (INECE), Fortaleza, Ceará, Brasil.

(2) Department of Internal Medicine, School of Medicine, Universidade Federal do Ceará, Fortaleza, Ceará, Brazil.

(3) Nephrology Division, Federal University of Rio Grande do Sul, RS, Brazil.

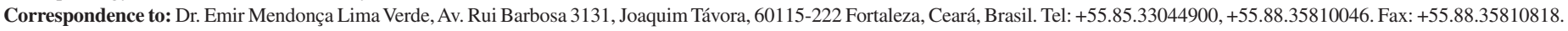
E-mail: elimaverde@hotmail.com 
only physical measures were used to fever control. All patients were from the rural zones and were diagnosed as having had daily fever for several weeks, increased abdominal volume and great hepatosplenomegaly. No patient had received kala-azar treatment previously. All patients had thorax radiographies before hospitalization.

The control group consisted of 20 individuals that annually had health tests and worked in the hospital. There was no evidence of cardiovascular, renal disease or systemic disease. They received the same diet and had frequent clinical examinations. The study protocol was registered and approved by ethical committees of both hospitals, and is in accordance with the Helsinki Declaration of 2000. All subjects agreed to participate in the study.

Clinical and laboratorial parameters: The following clinical parameters were investigated: demographic data, pre-existing diseases and current drug use. A complete physical examination was performed. All laboratory tests were performed in the Instituto de Nefrologia do Ceará, on the first and second days after the diagnosis of visceral leishmaniasis. All studies were performed beginning at 7AM after an overnight fast, with patients supine for $12 \mathrm{~h}$. The following parameters were measured: full blood count, total serum proteins, albumin and globulins, serum sodium and uric acid; plasma renin, ACTH, cortisol, aldosterone, TSH and free $\mathrm{T}_{4}$. First morning urine was collected simultaneously, and serum and urine osmolalities were determined. A daily urine sample was collected with patients on their usual diets for osmolality, sodium, urea and uric acid determinations. A second 24h-urine sample for 17-hydroxysteroids determination was collected using as conservation $20 \mathrm{~mL}$ of hydrochloric acid 8M. Creatinine clearance was calculated after fluid overload with $1500 \mathrm{~mL}$ of water drunk over 30 minutes. The bladder was empty and the time rigorously measured. There followed three periods of urine collection (one hour each) and mean creatinine clearance was calculated and adjusted to $1.73 \mathrm{~m}^{2}$ body surface area. Urinary fractional excretions of sodium, uric acid and urea were calculated in daily urine samples. Plasma ADH and serum sodium were measured simultaneously with serum and first morning urine osmolality determination.

Analytic methods: Total serum proteins were determined by the Biuret method, and albumin by the green bromocresol technique. Plasmatic colloidosmotic pressure (COP) was calculated by the LandisPappenheimer equation: COP $(\mathrm{mmHg})=2.1(\mathrm{TP})+0.16(\mathrm{TP})^{2}+0.009$ $(\mathrm{TP})^{3}$, where $\mathrm{TP}=$ serum total proteins $(\mathrm{g} / \mathrm{dL})$. Physiological limits of plasmatic colloidosmotic power were $25.4 \pm 2.3 \mathrm{~mm} \mathrm{Hg}^{26}$.
Serum and urinary osmolality were measured by cryoscopy with Precision Systems' Osmette A, USA. Creatinine was measured using modified Jaffé reaction, and uric acid was determined by the uricase method. Serum and urinary sodium and potassium were measured by ion selective electrode, AVL photometer model ISE 9180, USA. TSH, free $\mathrm{T}_{4}$, ACTH and cortisol were measured by chemiluminescence; antidiuretic hormone $(\mathrm{ADH})$ and aldosterone by radioimmunoassay. For urinary 17-hydroxysteroids, the Norymberski technique was used.

Statistical analysis: Clinical and laboratorial data were expressed as mean \pm standard deviation (SD) or percentages. Differences between two independent variables were evaluated using the t test or Mann-Whitney test as appropriate. The Epi info 2002 (Centers for Disease Control and Prevention) and SPSS 10.0 (SPSS Inc. Chicago, IL, USA) were used in all analyses. A p- value $<0.05$ was considered statistically significant.

\section{RESULTS}

All patients had daily fever, persistent nonproductive cough and splenomegaly. No cardiac disease was detected. Tachycardia was evident in routine electrocardiogram during feverish periods. Chest radiographies reveal increased reticular pattern of pulmonar fields, accentuated at bibasilar regions in 37 patients $(67.2 \%)$. Clinical symptoms of pneumonia and radiological evidences of pneumonic infiltration were seen in nine patients $(16.4 \%)$. Only one patient had detectable ascites. Mild low inferior limbs edema was present in thirteen patients (23.6\%).

Demographic and clinical data were compared in kala-azar patients and controls (Table 1). Forty seven patients were male $(85.4 \%)$, with a mean age of $28.6 \pm 11.0$ years (vs. controls $28 \pm 11$ years, $\mathrm{p}=0.325$ ) and eight $(14.5 \%)$ were female with a mean age of $17.4 \pm 8.1$ years (vs. controls $16 \pm 13$ years, $p=0.152$ ). Systolic and diastolic blood pressures were significantly lower in male kala-azar patients than in the control group. For females there was no difference. Supine blood pressure, lower than $100 / 60 \mathrm{mmHg}$ was detected in 22 patients (40\%). No patient had orthostatic hypotension. Body weight was significantly lower in kala-azar patients $(50.3 \pm 8.7$ vs. $63.5 \pm 11.4 \mathrm{~kg}, \mathrm{p}<0.005)$.

All patients had severe anemia with significant difference in hemoglobin levels in relation to control group $(7.9 \pm 1.4$ vs.14.2 \pm $0.8 \mathrm{~g} / \mathrm{dL}, \mathrm{p}<0.0001$ ) (Table 2 ). Total serum proteins ranged from 6.6 to $12.1 \mathrm{~g} / \mathrm{dL}$ and 20 patients $(36.3 \%)$ had increased total serum proteins levels. All patients presented hypoalbuminemia (range 0.8-

Table 1

Demographic and clinical data of kala-azar patients and controls

\begin{tabular}{|c|c|c|c|c|}
\hline & \multicolumn{2}{|c|}{ Kala-azar } & \multicolumn{2}{|c|}{ Controls } \\
\hline & $\mathrm{n}=47$ & $\mathrm{n}=8$ & $\mathrm{n}=17$ & $\mathrm{n}=3$ \\
\hline Sex & Male & Female & Male & Female \\
\hline Age (years) & $28.6 \pm 11.0^{\S}$ & $17.1 \pm 8.0^{\S}$ & $28.0 \pm 11$ & $16.0 \pm 13.0$ \\
\hline Systolic blood pressure $(\mathrm{mmHg})$ & $101.7 \pm 13.3^{* * *}$ & $91.4 \pm 14.6^{\S}$ & $120.3 \pm 6.1$ & $72.3 \pm 5.6$ \\
\hline Diastolic blood pressure $(\mathrm{mmHg})$ & $62.4 \pm 10.6^{* *}$ & $52.8 \pm 12.5^{\S}$ & $72.3 \pm 5.6$ & $65 \pm 5.0$ \\
\hline Body weight (Kg) & $51.0 \pm 7.8^{* * * *}$ & $39.8 \pm 11.1^{*}$ & $63.5 \pm 11.6$ & $59.9 \pm 7.9$ \\
\hline
\end{tabular}

Results expressed as mean $\pm \mathrm{SD}$; Descriptive level: ${ }^{*} \mathrm{p}<0.05,{ }^{* *} \mathrm{p}<0.005, * * * \mathrm{p}<0.0001, \S=$ not significant. 
$3.6 \mathrm{~g} / \mathrm{dL})$, and there was statistical difference to controls $(2.5 \pm 0.6$ vs. $4.6 \pm 0.5 \mathrm{~g} / \mathrm{dL}, \mathrm{p}<0.0001)$. Kala-azar patients had increased values of serum gammaglobulins (range 1.7-8.3 g/dL), and they were statistically different of controls $(3.7 \pm 1.6 \mathrm{vs} .1 .0 \pm 0.3 \mathrm{~g} / \mathrm{dL}$, $\mathrm{p}<0.0001)$. Intravascular colloidosmotic pressure, calculated by Landis-Pappenheimer equation ranged from 22.8 to $64.7 \mathrm{mmHg}$, and it was higher in kala-azar patients $(31.2 \pm 9.7$ vs. $26.4 \pm 1.6 \mathrm{~mm} \mathrm{Hg}$, $\mathrm{p}<0.005)$. Twenty one patients $(38.1 \%)$ had plasma colloidosmotic pressure in normal range (23-28 $\mathrm{mmHg})$, and 34 patients $(61.9 \%)$ had increased colloidosmotic pressure, with values above $28 \mathrm{mmHg}$. All patients had hyponatremia (sodium $<135 \mathrm{mEq} / \mathrm{L}$ ). Serum sodium ranged from 120 to $134 \mathrm{mEq} / \mathrm{L}$ with a statistical difference to controls $(129.3 \pm 4.5 \mathrm{vs} .139 .4 \pm 1.6 \mathrm{mEq} / \mathrm{L}, \mathrm{p}<0.0001)$. None of them presented symptoms related to hyponatremia. All patients had plasma hypoosmolality (Posm $<280 \mathrm{mOsm} / \mathrm{kg} \mathrm{H}_{2} \mathrm{O}$ ), and significant difference with controls $\left(269.5 \pm 8.4\right.$ vs. $\left.290.2 \pm 5.3 \mathrm{mOsm} / \mathrm{kg} \mathrm{H}_{2} \mathrm{O}\right)$. First morning urine osmolality showed lower values in kala-azar patients than in controls $\left(750.0 \pm 52.0\right.$ vs. $\left.894.5 \pm 30.0 \mathrm{mOsm} / \mathrm{kg} \mathrm{H} \mathrm{H}_{2} \mathrm{O}, \mathrm{p}<0.05\right)$, but they may be considered as having good urinary concentration capacity.

Table 2

Laboratory findings of patients with kala-azar and controls

\begin{tabular}{|c|c|c|}
\hline & $\begin{array}{c}\text { Kala-azar } \\
n=55\end{array}$ & $\begin{array}{c}\text { Controls } \\
n=20\end{array}$ \\
\hline Blood hemoglobin (g/dL) & $7.9 \pm 1.4^{* * * *}$ & $14.2 \pm 0.8$ \\
\hline Serum total proteins $(\mathrm{g} / \mathrm{dL})$ & $7.8 \pm 1.4^{\S}$ & $7.4 \pm 0.4$ \\
\hline Serum albumin (g/dL) & $2.5 \pm 0.6^{* * *}$ & $4.6 \pm 0.5$ \\
\hline Serum gammaglobulins (g/L) & $3.7 \pm 1.6^{* * *}$ & $1.0 \pm 0.3$ \\
\hline $\begin{array}{l}\text { Plasma colloidosmotic pressure } \\
(\mathrm{mmHg})\end{array}$ & $30.7 \pm 7.1^{* *}$ & $26.4 \pm 1.6$ \\
\hline Serum sodium (mEq/L) & $129.3 \pm 4.5^{* * *}$ & $139.4 \pm 1.6$ \\
\hline Urinary sodium $(\mathrm{mEq} / \mathrm{L})$ & $82.3 \pm 44.2^{* *}$ & $110.3 \pm 34.7$ \\
\hline Serum potassium $(\mathrm{mEq} / \mathrm{L})$ & $3.7 \pm 0.4^{*}$ & $4.0 \pm 0.3$ \\
\hline Urinary potassium (mEq/L) & $23.2 \pm 11.1^{* * * *}$ & $39.4 \pm 10.7$ \\
\hline $\begin{array}{l}\text { Serum osmotic pressure } \\
\left(\mathrm{mOsm} / \mathrm{kg} \mathrm{H}_{2} \mathrm{O}\right)\end{array}$ & $269.5 \pm 8.4^{* * *}$ & $290.2 \pm 5.3$ \\
\hline $\begin{array}{l}1^{\text {st }} \text { urine osmotic pressure } \\
\left(\mathrm{mOsm} / \mathrm{kg} / \mathrm{H}_{2} \mathrm{O}\right)\end{array}$ & $750.0 \pm 52.0^{*}$ & $894.5 \pm 30.0$ \\
\hline Serum urea (mg/dL) & $29.3 \pm 11.3^{* *}$ & $34.7 \pm 2.8$ \\
\hline Urinary urea (mg/d) & $18.2 \pm 8.1^{* *}$ & $24.6 \pm 6.5$ \\
\hline Fractional urea excretion (\%) & $47.3 \pm 11.4^{\S}$ & $53.8 \pm 15.7$ \\
\hline Serum uric acid (mg/dL) & $3.3 \pm 1.5^{* *}$ & $4.4 \pm 1.0$ \\
\hline Urinary uric acid (mg/d) & $782.7 \pm 306.6^{* * *}$ & $575.2 \pm 185.0$ \\
\hline $\begin{array}{l}\text { Fractional urinary uric acid } \\
\text { excretion }(\%)\end{array}$ & $18.7 \pm 13.6^{* *}$ & $10.2 \pm 3.1$ \\
\hline $\begin{array}{l}\text { Creatinine clearance } \\
\left(\mathrm{mL} / \mathrm{min} / 1.73 \mathrm{~m}^{2}\right)\end{array}$ & $120.7 \pm 21.4^{*}$ & $110.4 \pm 20.7$ \\
\hline
\end{tabular}

Results expressed as mean $\pm \mathrm{SD}$; osm = osmolality ; Descriptive level: ${ }^{*} \mathrm{p}<0.05,{ }^{* *} \mathrm{p}<0.005,{ }^{* * *} \mathrm{p}<0.0001, \S=$ not significant.
No patient presented urinary osmolality under $250 \mathrm{mOsm} / \mathrm{kg} \mathrm{H}_{2} \mathrm{O}$, showing a lack of capacity to produce diluted urine $\mathrm{f}^{7}$ Urine osmolality was inappropriately high in relation to serum osmolality, meaning the persistence of $\mathrm{ADH}$ secretion during the whole 24-hours period. Urinary sodium excretion was significantly lower in kala-azar patients than in controls $(82.3 \pm 44.2$ vs. $110.3 \pm 34.7 \mathrm{mEq} / \mathrm{L}, \mathrm{p}<0.05)$. No patient had urinary sodium concentration under $30 \mathrm{mEq} / \mathrm{L}$. Fractional urinary sodium excretion (range 0.3 to $3.9 \%)$ was similar to controls: $(0.9 \pm 0.8$ vs.0.7 $\pm 0.2 \%, \mathrm{p}=0.2028)$. Urinary potassium excretion was significantly lower in kala-azar patients than in controls $(23.2 \pm 11.1$ vs. $39.4 \pm 10.7$ $\mathrm{mEq} / \mathrm{L}, \mathrm{p}<0.005)$.

Hypochloremia (serum chlorum $<96 \mathrm{mEq} / \mathrm{L}$ ) was found in 17 patients $(30.9 \%)$

Serum urea $(29.3 \pm 11.3$ vs. $34.7 \pm 2.8 \mathrm{mg} / \mathrm{dL}, \mathrm{p}<0.005)$, and $24-$ hour urinary urea excretion $(18.2 \pm 8.1$ vs. $24.6 \pm 6.5 \mathrm{~g} / \mathrm{d}, \mathrm{p}<0.005)$ were lower in kala-azar patients than in the control group. Serum urea was lower than $20.0 \mathrm{mg} / \mathrm{dL}$ in 26 patients $(47.2 \%)$. Fractional urinary urea excretion $(47.3 \pm 11.4$ vs. $53.8 \pm 15.7 \%, \mathrm{p}=0.627)$ was not significantly different to the control group.

Serum uric acid (range1.8-6.4 mg/dL) was lower than $4.0 \mathrm{mg} / \mathrm{dL}$ in 34 patients $(61.8 \%)^{7}$. Mean serum uric acid $(3.3 \pm 1.5$ vs. $4.4 \pm 1.0 \mathrm{mg} / \mathrm{dL}, \mathrm{p}$ $<0.005)$ was lower in kala-azar patients. Daily urinary uric acid excretion $(782.7 \pm 306.6$ vs. $575.2 \pm 185.0 \mathrm{mg} / \mathrm{d}, \mathrm{p}<0.005)$ was significantly higher in kala-azar patients. Fractional urinary uric acid excretion ranged from 6.1 to $77 \%$, and it was increased in 41 patients $(74.5 \%)$, significantly different to the control group $(18.7 \pm 13.6$ vs. $10.2 \pm 3.1 \%, \mathrm{p}<0.005)$.

Creatinine clearance was significantly higher in kala-azar patients $\left(120.7 \pm 21.4\right.$ vs. $\left.110.4 \pm 20.7 \mathrm{~mL} / \mathrm{min} / 1.73 \mathrm{~m}^{2}, \mathrm{p}<0.05\right)$. Patients with low creatinine clearances $\left(\mathrm{Ccr}<85 \mathrm{~mL} / \mathrm{min} / 1.73 \mathrm{~m}^{2}\right)$ were excluded due the presence of water and electrolyte disturbances in low renal function patients. Increased glomerular filtration rate $\left(\mathrm{Ccr}>130 \mathrm{~mL} / \mathrm{min} / 1.73 \mathrm{~m}^{2}\right)$ was present in 14 patients $(25.4 \%)$.

Plasma ADH (Table 3) measured in 23 kala-azar patients $(41.8 \%)$ was higher than controls, but had no significant difference: $(5.6 \pm 1.1 \mathrm{vs}$. $5.1 \pm 3.4 \mathrm{pg} / \mathrm{mL}, \mathrm{p}=0.0635$ ). Plasma ACTH ranged from 12 to $73 \mathrm{pg} /$ $\mathrm{mL}$, and it was within the physiological range. Plasma ACTH was not significantly different to the control group $(38.6 \pm 0.09$ vs. $43.2 \pm 12.3$ $\mathrm{pg} / \mathrm{mL}, \mathrm{p}=0.840)$. Eleven patients $(20.0 \%)$ had normal ACTH plasma levels and low plasma cortisol concentrations. Plasma cortisol levels (range13 to $34 \mu \mathrm{g} / \mathrm{dL}$ ) were significantly higher in kala-azar patients $(19.0 \pm 7.1 \mathrm{vs} .14 .0 \pm 3.9 \mu \mathrm{g} / \mathrm{dL}, \mathrm{p}<0.005)$. Cortisol plasma levels were lower than $18 \mu \mathrm{g} / \mathrm{dL}$ in $20.0 \%$ of patients, which had low daily urinary 17-hydroxysteroids too. Daily urinary 17-hydroxysteroids $(25.5 \pm 19.7$ vs. $8.8 \pm 1.2 \mathrm{mg} / \mathrm{d}, \mathrm{p}<0.005)$ were higher in kala-azar patients and they were increased (> $12 \mathrm{mg} / \mathrm{d})$ in 44 patients $(80 \%)$.

Plasma renin levels were significantly higher in kala-azar patients $(3.1 \pm 3.8$ vs. $1.0 \pm 0.2 \mathrm{ng} / \mathrm{mL} / \mathrm{h}), \mathrm{p}<0.05)$. Plasma renin was increased $(>2.6 \mathrm{ng} / \mathrm{mL} / \mathrm{h})$ in 13 patients $(23.6 \%)$. Plasma aldosterone levels were significantly lower in kala-azar patients $(5.4 \pm 3.6 \mathrm{vs} .11 .6 \pm 7.2 \mathrm{ng} / \mathrm{dL}$, $\mathrm{p}<0.005)$. Low plasma aldosterone levels $(<3.0 \mathrm{ng} / \mathrm{dL})$ were observed in 18 patients $(32.7 \%)$. Daily urinary aldosterone excretion $(5.9 \pm 3.5$ vs. $5.5 \pm 1.5 \mu \mathrm{g} / \mathrm{d}, \mathrm{p}=0.0623$ ) was not significantly different to controls. 
LIMA VERDE, F.A.; LIMA VERDE, F.A.A.; VERONESE, F.J.V.; NETO, A.S.; FUC, G. \& LIMA VERDE, E.M. - Hyponatremia in visceral leishmaniasis. Rev. Inst. Med. Trop. Sao Paulo, 52(5): 253-8, 2010.

Table 3

Laboratory findings of patients with kala-azar and controls

\begin{tabular}{lcc}
\hline & $\begin{array}{c}\text { Kala-azar } \\
\mathrm{n}=55\end{array}$ & $\begin{array}{c}\text { Controls } \\
\mathrm{n}=20\end{array}$ \\
\hline ADH $(\mathrm{pg} / \mathrm{mL})$ & $5.6 \pm 1.1^{\S}$ & $5.1 \pm 3.7$ \\
ACTH $(\mathrm{pg} / \mathrm{mL})$ & $39.8 \pm 0.2^{*}$ & $30.2 \pm 0.3$ \\
Renin $(\mathrm{ng} / \mathrm{mL} / \mathrm{h})$ & $3.1 \pm 3.8^{*}$ & $1.0 \pm 0.2$ \\
Aldosterone $(\mathrm{ng} / \mathrm{dL})$ & $5.4 \pm 3.6^{* *}$ & $11.6 \pm 7.2$ \\
Cortisol $(\mu \mathrm{g} / \mathrm{dL})$ & $19.0 \pm 7.1^{* *}$ & $14.0 \pm 3.9$ \\
Urine aldosterone $(\mu \mathrm{g} / \mathrm{d})$ & $0.2 \pm 0.1^{\S}$ & $0.16 \pm 0.04$ \\
Urine $17-\mathrm{hydroxysteroids}(\mathrm{mg} / \mathrm{d})$ & $25.5 \pm 19.7^{* *}$ & $8.8 \pm 1.2$ \\
TSH $(\mu \mathrm{IU} / \mathrm{mL})$ & $2.8 \pm 2.1^{\S}$ & $2.5 \pm 2.0$ \\
$\mathrm{~T}_{4}$ free $(\mathrm{ng} / \mathrm{mL})$ & $1.2 \pm 0.6^{\S}$ & $1.5 \pm 0.3$ \\
\hline
\end{tabular}

$\mathrm{ADH}$ - antidiuretic hormone; $\mathrm{TSH}$ - Thyroid stimulating hormone, $\mathrm{T}_{4}$ - free thyroxin; Results as mean \pm SD. Descriptive level: ${ }^{*} \mathrm{p}<0.05,{ }^{* *} \mathrm{p}<0.005,{ }^{* * * *} \mathrm{p}<0.0001$, $\S=$ not significant.

Thirteen patients $(23.6 \%)$ had high plasma renin and 42 patients (76.4\%) had normal plasma renin concentrations ( $5.7 \pm 4.6$ vs. $1.4 \pm 0.7$ $\mathrm{ng} / \mathrm{mL} / \mathrm{h}, \mathrm{p}<0.0001)$. Patients with high plasma renin levels had higher plasma aldosterone $(7.2 \pm 3.6 \mathrm{vs} .3 .6 \pm 2.8 \mathrm{ng} / \mathrm{dL}, \mathrm{p}<0.05)$. They also had high urinary sodium concentrations $(100 \pm 55 \mathrm{vs} .76 \pm 39 \mathrm{mEq} / \mathrm{L}, \mathrm{p}<$ $0.05)$. There were no statistical differences between two groups, when the levels of serum sodium $(131 \pm 3.8 \mathrm{vs} .128 \pm 4.4 \mathrm{mEq} / \mathrm{L})$, serum potassium $(3.7 \pm 0.3$ vs. $3.8 \pm 0.4 \mathrm{mEq} / \mathrm{L})$, plasma coloidosmotic pressure $(312 \pm$ 107 vs. $313 \pm 92 \mathrm{mmHg})$ and fractional urinary sodium excretion $(0.6$ \pm 0.5 vs. $0.7 \pm 0.5 \%$ ) were compared. Patients with increased plasma renin concentrations, had no evidence of extracelular volume depletion. Eleven patients $(84.7 \%)$ with high plasma renin concentrations had serum uric acid below $4.0 \mathrm{mg} / \mathrm{dL}(4.2 \pm 1.3 \mathrm{mg} / \mathrm{dL})$ and increased uric acid excretion fraction $(22.2 \pm 18.5 \%)$, showing no difference between kala-azar patients with normal and with increased plasma renin levels.

Thyroid-stimulating hormone (TSH) plasma levels of kala-azar patients was not statistically different $(2.8 \pm 2.1$ vs. $2.5 \pm 2.0 \mu \mathrm{IU} / \mathrm{mL}$, $\mathrm{p}=0.6274)$. Free $\mathrm{T}_{4}$ plasma levels of kala-azar patients did not show significant difference from the control group $(1.2 \pm 0.6$ vs. $1.5 \pm 0.3 \mathrm{ng} /$ $\mathrm{mL}, \mathrm{p}=0.3382$ ).

\section{DISCUSSION}

Daily fever, sweating, diarrhea and vomiting are present in kala-azar patients and may be important features to induce water and electrolyte disturbances. These patients manifest accentuate weight loss, but paradoxically preserve a good appetite during all disease evolution, which assures them a regular intake of fluids and sodium chloride. Kala-azar patients present characteristically a enormous splenomegaly, that induces to severe anemia, leucopenia and thrombocytopenia. Low blood pressure values are frequently observed in kala-azar patients, without evidence of orthostatic hypotension. Recently hyponatremia has been described in kala-azar patients of different groups ${ }^{20,21,25}$. All these features may be present in patients with extracellular volume depletion and hypovolemia. The physiological response to hypovolemia would be vasopressin secretion, and through the stimulus of the renin-angiotensinsystem, secondary aldosterone production.

Hyponatremic individuals, due to extra-renal causes and carriers of volume depletion, present low levels of urinary sodium, generally under $20 \mathrm{mEq} / \mathrm{L}^{8}$. Urinary sodium was high in all kala-azar patients, and fractional urinary sodium excretion stayed within the normal range, independently of the plasma renin concentration, ruling out the possibility of extracellular volume depletion. The urea excretion fraction of kalaazar patients was similar to the control group, a physiological parameter frequently decreased in patients with extracellular fluid depletion.

Nearly one fourth of kala-azar patients presented high levels of plasma renin, while their plasma aldosterone levels stayed in normal range, a possible evidence of decreased adrenal response to the high plasma renin levels or to the presence of a physiological block to aldosterone secretion, as hypokalemia, potassium depletion or expanded water space.

Patients with high and normal plasma renin levels showed no difference in relation to sodium and potassium serum levels, as to daily urinary sodium excretion and the plasma colloidosmotic pressure values. Tendency to low potassium serum levels are evident in kala-azar patients and probably indicate the coexistence of body potassium depletion.

Carriers of low adrenal activity frequently have hyponatremia with high urinary sodium concentrations, and characteristically increased serum levels of potassium, urea and creatinine. Kala-azar patients, on the other side, had low plasma concentrations of aldosterone, potassium, urea and creatinine.

Most kala-azar patients presented plasma cortisol values higher than $18 \mu \mathrm{g} / \mathrm{dL}^{11}$ and increased daily excretion of urinary 17-hydroxysteroids, assuring the presence of good adrenal function and making remote the possibility of adrenal insufficiency. One fifth of patients present normal ACTH and cortisol plasma levels with normal 17-hydroxysteroids urinary excretion, their real adrenal activity being difficult to evaluate.

Blood acid-base studies in kala-azar patients had not detected the presence of metabolic acidosis as commonly observed in low adrenal activity patients ${ }^{21}$.

Normal TSH and free $\mathrm{T}_{4}$ plasma levels indicated sufficient thyroid hormone secretion to supply the basic needs of the organism in kala-azar patients, rejecting the possibility of water retention and hyponatremia, due to thyroid hormone deficiency.

Hyponatremia has been also observed in malnourished patients. Kala-azar patients maintain an adequate food intake as observed by the daily urinary phosphate excretion ${ }^{20}$. Malnourished patients differ from kala-azar patients, particularly because they manifest reduced glomerular filtration rate $^{2}$.

Kala-azar patients present many features of the syndrome of inappropriate antidiuretic hormone secretion (SIADH). This syndrome is described in normovolemic or hypervolemic patients, and results in excessive water retention at distal and collecting ducts, despite low levels of extracellular fluid osmolality. Its main characteristics are: hyponatremia and hypo-osmolality, persistently increased urinary 
sodium excretion and urine osmolality, with preserved renal and adrenal functions ${ }^{6,30}$.

Hyponatremia and hypo-osmolality were found in all patients with visceral leishmaniasis of the present study, and persisted throughout the active phase of the disease. Despite serum hypo-osmolality, kala-azar patients produced highly concentrated urine, as evidenced in the first morning samples, and in the 24-hourly urine collections. No patient had urine osmolality lower than $250 \mathrm{mOsm} / \mathrm{kg} \mathrm{H}_{2} \mathrm{O}$, a necessary condition for sufficient free water formation and aqueous diuresis production, with consequent plasma hypo-osmolality correction ${ }^{7}$. Kala-azar patients had higher plasma ADH levels. They had high urinary concentration capacity, but lower than that of the control group. This discrepancy may result of the presence of interstitial nephritis as the predominant kidney lesion of kala-azar patients ${ }^{13}$.

Hypoalbuminemia is part of the classical form of chronic kalaazar, and was a constant in all kala-azar patients. It results from liver dysfunction, decreased albumin synthesis and reduction in intestinal absorption of proteins due to a protein losing enteropathy ${ }^{27}$. Low serum albumin concentrations decrease the plasma colloidosmotic pressure, and may reduce intravascular negative charges induced to lower $\mathrm{Na}^{+}$ attraction into vascular space (Gibbs-Donnan equilibrium), accentuating the hiponatremia ${ }^{15}$.

Hypergammaglobulinemia was a typical feature of kala-azar patients, and results from intense production of polyclonal antibodies, particularly G immunoglobulins.

Very little research has been given to the intravascular volume status in visceral leishmaniasis. Blood volume determinations using radioiron ${ }^{59} \mathrm{Fe}$ and radio-chromium ${ }^{51} \mathrm{Cr}$ have evidenced normal values ${ }^{17}$. On the other side, expanded intravascular volume has been extensively documented using T-1824 dye method, in patients with splenomegaly and visceral leishmaniasis ${ }^{23,31}$.

In vivo and in experimental research, the calculation of plasma colloidosmotic pressure using the Landis-Pappenheimer equation, gives excellent results. The values are similar to those directly measured with oncometers $^{28}$. The results nearly give an idea of the volemic state, when plasma albumin concentrations are above $1.0 \mathrm{~g} / \mathrm{dL}$, as that observed in the kala-azar patients ${ }^{24}$. By applying the equation, all kala-azar patients have normal or predominantly increased colloidosmotic pressure. The presence of increased plasma gammaglobulin concentrations exceed the decreased contribution of the hypoalbuminemia, and produce a normal or increased colloidosmotic pressure in kala-azar patients. The expansion of the intravascular volume can explain the increased values of glomerular filtration rate observed in kala-azar patients.

Proximal tubular dysfunction affecting the reabsorption of proteins, light chains, sodium, potassium, magnesium, calcium, inorganic phosphate and glucose has recently been observed in kala-azar patients, and was also attributed to expanded water space ${ }^{19}$. Similarly, findings have been described in patients with different pathologies associated to the syndrome of inappropriate antidiuretic hormone secretion ${ }^{16,35}$.

Increased plasma renin levels, low plasma aldosterone concentrations and low daily urinary aldosterone excretion were observed in one-third of kala-azar patients. These alterations have been described also in critically ill and hypotensive patients ${ }^{37}$. Total body water expansion and potassium depletion (vomiting, diarrhea, urinary potassium loss) may act as potent blocks to aldosterone secretion by adrenal glands in kala-azar patients. Hypochloremia and low urea serum levels may be evidence of decreased protein ingestion and/or body water expansion ${ }^{18}$. Hypouricemia and increased fractional urinary uric acid excretion are other features of kala-azar patients. Reduction of proximal uric acid reabsorption leads to increased uric acid delivery to distal and collecting ducts, resulting in a greater uric acid excretion ${ }^{1,7}$.

The syndrome of antidiuretic hormone secretion in kala-azar patients may be started by interstitial pneumonitis described in $76.8 \%$ of necropsied patients ${ }^{12}$. The widespread and intensive inflammatory state involving the lungs, the liver, the kidneys, the intestines and the lymphatic ganglia induced to increase production of plasma prostaglandins and renin ${ }^{9,29,33,34}$. High serum levels of interleukin-6 have been detected in visceral leishmaniasis $\mathrm{s}^{3,32}$ and can act as a potent stimulus of the hypothalamicpituitary-adrenal axis and to arginine vasopressin(ADH) release too ${ }^{14,22}$.

\section{CONCLUSION}

Kala-azar patients present malnutrition, anemia, hipoalbuminemia, and hypergammaglobulinemia. Hyponatremia, serum hypo-osmolality and high urine osmolality reflect persistent antidiuretic hormone secretion, without production of sufficient free water for plasmatic hypotonicity correction. Urine sodium excretion remains comparable to that of normal patients. Increased urinary uric acid excretion fraction, hypouricemia, and the absence of adrenal and thyroid insufficiency suggest the possibility of the syndrome of inappropriate antidiuretic hormone secretion in most kala-azar patients.

\section{RESUMO}

\section{Hiponatremia no calazar}

Existem poucos relatos relacionando hiponatremia com a leshmaniose visceral (calazar). Este é um estudo de 55 pacientes portadores de calazar e um grupo controle de 20 indivíduos normais. Hiponatremia e hipo-osmolalidade sérica foram detectados em $100 \%$ dos pacientes portadores de calazar. A presença de alta osmolalidade da primeira urina da manhã $\left(750,0 \pm 52,0\right.$ vs. $894,5 \pm 30 \mathrm{mOsm} / \mathrm{Kg} \mathrm{H}_{2} \mathrm{O}$, $\mathrm{p}<0,05)$ e da urina de $24 \mathrm{~h}(426,0 \pm 167,0$ vs. $514,6 \pm 132,0 \mathrm{mOsm} / \mathrm{Kg}$ $\left.\mathrm{H}_{2} \mathrm{O}, \mathrm{p}<0,05\right)$, demonstraram a presença de persistente secreção de hormônio antidiurético. A concentração de sódio urinário foi elevada $(82,3 \pm 44,2$ vs. $110,3 \pm 34,7 \mathrm{mEq} / \mathrm{L}, \mathrm{p}<0,05)$. Hipouricemia ocorreu em $61,8 \%$ dos pacientes e aumento da fração de excreção urinária de ácido úrico foi detectada em $74,5 \%$ dos casos. Aumento da velocidade de filtração glomerular estava presente em $25,4 \%$ dos pacientes. Não havia evidência clínica de depleção de volume extracelular. Valores normais de ADH plasmático foram observados nos pacientes com calazar. Não foi detectada disfunção renal ou endócrina. É provável, que a maioria dos pacientes com calazar apresente uma síndrome de secreção inapropriada de hormônio antidiurético.

\section{ACKNOWLEDGMENTS}

The authors are grateful to the team of physicians, residents, medical 
students and nurses of Hospital São José de Doenças Infecciosas and to the Hospital Geral de Fortaleza for allowing the inclusion of patients in this study, as well as to the Instituto de Nefrologia do Ceará for technical and financial support.

\section{REFERENCES}

1. Akalin E, Chandrakantan A, Keane J, Hamburger RJ. Normouricemia in the syndrome of inappropriate antidiuretic hormone secretion. Am J Kidney Dis. 2001;37(1): E8.

2. Alleyne GAO.The effect of severe protein calorie malnutrition on the renal function of Jamaican children. Pediatrics.1967;39:400-11.

3. Ansari NA, Saluja S, Salotra P. Elevated levels of interferon- $\gamma$, interleukin-10 and interleukin-6 during active disease in Indian kala-azar. Clin Immunol. 2006;119:339-45.

4. Badaró R, Duarte MIS. Leishmaniose visceral. In: Veronesi R, Focaccia R, editores. Tratado de infectologia. $3^{\text {a }}$ ed. São Paulo: Atheneu; 2007. p. 1563-90.

5. Bartter FC, Schwartz WB. The syndrome of inappropriate secretion of antidiuretic hormone. Am J Med.1967;42:790-806.

6. Baylis PH. The syndrome of inappropriate antidiuretic hormone secretion. Int J Biochem Cell Biol. 2003;35:1495-9.

7. Beck LH. Hypouricemia in the syndrome of inappropriate secretion of antidiuretic hormone. N Engl J Med.1979;301:528-30.

8. Berl T, Verbalis J. Disorders of water balance In: Brenner \& Rector's, editors. The kidney. $8^{\text {th }}$ ed. Boston: Saunders, 2007. p. 491-504

9. Brandonisio O, Panaro MA, Sisto M, Acquafredda A, Fumarola L, Leogrande D, et al. Nitric oxide production by Leishmania-infected macrophages and modulation by cytoquines and prostaglandins. Parassitologia.2001;43(suppl 1):1-6.

10. Carvalho EM, Barral A, Pedral-Sampaio D, Barral-Netto M, Badaró R, Rocha J, et al. Immunological markers of clinical evolution in children recently infected with Leishmania donovani chagasi. J Infect Dis.1992;165:535-40.

11. Dluhy AS. Disorders of adrenal cortex. In: Fauci AS, Braunwald E, Kasper LH, Hauser SL, Longo Dan L, Jameson JL, Loscalzo J, editors. Harrisson's principles of internal medicine. New York: Mc Graw-Hill; 2008. p. 7118-78.

12. Duarte MIS, Matta VLR, Corbett CEP, Lurenti MD, Chebabo R, Goto H. Interstitial pneumonitis in human visceral leishmaniasis. Trans R Soc Trop Med Hyg. 1989;83:73-76

13. Duarte MIS, Silva MRR, Goto H, Nicodemo EL, Amato Neto V. Interstitial nephritis in human kala-azar. Trans R Soc Trop Med Hyg.1983;77:531-7.

14. Gionis D, Ilias I, Moustaki M, Mantzos E, Papadatos I, Koutras DA, et al. Hypothalamic-pituitary-adrenal axis and interleukin-6 activity in children with head trauma and syndrome of inappropriate secretion of antidiuretic hormone. J Pediatr Endocrinol Metabol. 2003;16:49-54.

15. Halperin ML, Goldstein MB. Fluid, electrolyte and acid-base physiology. $3^{\text {rd }}$ ed. Philadelphia: Saunders, 1999. p. 227-328.

16. Ishii T, Ohtake T, Yasu T, Kadotani Y, Hayashi S, Oka M, et al. A rare case of combine syndrome of innapropriate antidiuretic hormone secretion and Fanconi syndrome in an elderly woman. Am J Kidney Dis. 2006;48:155-8.

17. Knight R, Woodruff AW, Pettitt LE. The mechanism of anaemia in kala-azar: a study of 2 patients. Trans R Soc Trop Med Hyg.1967;61:701-5.

18. Liamis G, Christidis D, Alexandridis G, Bairaktari E, Madias NE, Elisaf M. Uric acid homeostasis in the evaluation of diuretic-induced hyponatremia. J Invest Med. 2007;55:36-44
19. Lima Verde FAA, Lima Verde FA, Daher EF, Santos GM, Saboia Neto A, Lima Verde EM. Renal tubular dysfunction in human visceral leishmaniasis (Kala-azar). Clin Nephrol.2009;71:492-500.

20. Lima Verde FAA, Lima Verde FA, Lima Verde IA, Silva Junior GB, Daher EF, Lima Verde EM. Evaluation of renal function in human visceral leishmaniasis ( Kala-azar): a prospectivetive study on 50 patients from Brazil. J Nephol. 2007;20:430-6.

21. Lima Verde FA, Santos GM, Lima Verde FAA, Daher EF, Saboia Neto A, Lima Verde EM. Distúrbios ácido-base na leishmaniose visceral. J Bras Nefrol. 2008;30:172-179.

22. Mastorakos G, Weber JS, Magiakou MA, Gunnb H, Chrousos GP. Hypothalamicpituitary-adrenal axis and stimulation of systemic vasopressin secretion by recombinant Interleukin-6 in humans: potential implications for the syndrome of inappropriate vasopressin secretion. J Clin Endocrinol Metab.1994;79:934-9.

23. Mc Fadzean AJS, Todd D, Tsang KC. Observations on the anemia of criptogenetic splenomegaly. II. Expansion of the plasma volume. Blood. 1958;13:524-32.

24. Miller PL, Meyer TW. Plasma protein concentration and colloid osmotic pressure in nephrotic rats. Kidney Int. 1988;34:220-3.

25. Minodier P, Piarroux R, Garnier JM, Unal D, Perrimond H, Dumon H. Pediatric visceral leishmaniasis in Southern France. Pediatr Infect Dis J. 1998;17:701-4.

26. Morissette MP. Colloid osmotic pressure: its measurement and clinical value. Can Med Ass J. 1977;116:897-900

27. Muigai R, Gatei DG, Shaunak S, Wozniak A, Bryceson AD. Jejunal function and pathology in visceral leishmaniasis. Lancet. 1983;2:476-9.

28. Mullins RE, Pappas AA, Gadsden RH. Correlation of standardized serum protein determinations with calculated and measured colloid osmotic pressure. Am J Clin Path. 1983;80:170-5.

29. Murakami T, Matoba H, Kuga Y, Ozawa S, Kubota K, Yoshida S. Hyponatremia in a patient in a chronic inflammatory disease. Intern Med. 1998;37:792-5.

30. Nolph KD, Schrier RW. Sodium, potassium and water metabolism in the syndrome of inappropriate antidiuretic hormone secretion. Am J Med. 1970;49:534-45.

31. Pippard MJ, Moir D, Weatherall DJ, Lenicker HM. Mechanism of anemia in resistant visceral leishmaniasis. Ann Trop Med Parasitol.1986;80:317-23.

32. Poll T, Zijlstra EE, Mevissen M. Interleukin 6 during active visceral leishmaniasis and after treatment. Clin Immunol Immunopathol.1995;77:111-4.

33. Reiner NE, Malemud CJ. Arachidonic acid metabolism by murine peritoneal macrophages infected with Leishmania donovani: in vitro evidence for parasite-induced alterations in ciclooxigenase and lypooxygenase pathways. J Immunol. 1985;134:556-63.

34. Reiner NE, Schultz LA, Malemud CJ. Eicosanoid metabolism by Leishmania donovani-infected macrophages: mouse strain response in prostanoid synthesis. Am J Trop Med Hyg. 1988;38:59-64.

35. Rizos E, Liamis G, Elisaf M. Multiple metabolic abnormalities in a patient with the syndrome of inappropriate antidiuresis. Nephron. 2002;91:339-40.

36. Totan M, Hokelek M, Cetinkaya MC. Five pneumonia cases associated with visceral leishmaniasis in Turkey. Intern Pediatr. 2003;18:185-7.

37. Zipser RD, Davenport MW, Martin KL, Tuck ML, Warner NE, Swinney RR, et al Hyperreninemic hypoaldosteronism in the critically ill: a new entity. J Clin Endocrinol Metab. 1981;53:867-73.

Received: 10 May 2010

Accepted: 10 August 2010 